\title{
AS QUATRO ESTAÇÕES DE CARLOS FRANCISCO DE MORAIS
}

\section{THE FOUR SEASONS OF CARLOS FRANCISCO DE MORAIS}

\author{
Jairo Nogueira Luna ${ }^{1}$
}

RESUMO: O romance As Quatro Estações, de Carlos Francisco de Morais, apresenta um panorama significativo de relações estéticas, sócio-culturais e artístico-literárias que confluem para uma interpretação do cosmopolitismo de São Paulo e, ao mesmo tempo, para uma exemplificação de características neobarrocas. Aqui, buscamos analisar alguns desses aspectos, demonstrando, na articulação das partes do romance, uma analogia com a obra de mesmo título de Vivaldi, com destaque para os sonetos que originalmente faziam parte do libreto da obra musical, além de também observarmos analogias com aspectos da pintura presentes no romance. Assim, pretendemos pôr em relevo elementos que a nosso ver se destacam na estrutura da obra, tanto nos aspectos semânticos quanto nos aspectos microestruturais da escrita do autor.

PALAVRAS-CHAVE: Romance brasileiro contemporâneo, neobarroco, Vivaldi, São Paulo, cosmopolitismo.

ABSTRACT: The romance The four seasons, of Carlos Francisco de Morais, presents a significant socio-cultural and artistic-literary panorama of aesthetic relations, and converge to an interpretation of cosmopolitanism of São Paulo and at the same time to exemplify the neo-baroque features. Here, we analyze some of these aspects, demonstrating the articulation of parts of the romance, analogy with the work of Vivaldi, especially the sonnets which were originally part of the libretto of the musical work, and also observe similarities with aspects of painting present in the romance. Thus, we intend to put into relief elements which in our view are highlighted in the structure of the work, both in semantic aspects as the microstructural aspects of the author's writing.

KEYWORDS: Romance contemporary Brazilian, neobarroco, Vivaldi, São Paulo, cosmopolitanism.

\section{Introdução}

Neste breve artigo, teço alguns comentários acerca da obra As Quatro Estações, da autoria de Carlos Francisco de Morais (2013). Conheço o autor desde o tempo em que dávamos aulas na Universidade Cruzeiro do Sul, em São

\footnotetext{
${ }^{1}$ Professor Doutor na Universidade de Pernambuco (UPE).
} 
Paulo, e sei do seu gosto refinado em termos de literatura e de arte. Nesse sentido, não foi surpresa para mim que, na leitura de seu romance, esse aspecto se destacasse como elemento constituinte da obra. Como sugere o título, o livro está dividido em quatro partes, intituladas por cada uma das quatro estações do ano, começando pelo Verão e terminando pela Primavera. Ordenação de começo e fim muito sugestiva, já que se parte da estação mais quente, auge da luz diária, passa-se pelo período de queda das folhas, do frio intenso, para ser renovar ao fim as esperanças com a Primavera.

\section{Alguns comentários sobre o enredo e sua significação:}

\subsection{A cidade de São Paulo: encontros e desencontros}

Logo no início da leitura, alguns elementos constitutivos da obra vão se destacar, ou seja, os cenários e ambientes: São Paulo, Itália, galerias de arte, ruas e avenidas significativas da cidade de São Paulo. O personagem Adriano, que estuda em Milão e conhece a personagem Teresa, conhecida como Flor, na Galleria Borghese, em Roma, tem um nome muito característico para ressignificar sua ligação com a Itália:

- Adriano dos Santos Dell'Acqua, um criado seu.

- Você tem nome de imperador romano e sobrenome italiano?

- Um negro italianado? Pois é, coisas do Brasil, prodígios de São Paulo, da Bela Vista... Vestígios de um pai como não há igual. (MORAIS, p. 17)

É a figura mitológica de Vênus, não por acaso, que Adriano e Teresa se encontram primeiramente admirando na pintura de Ticiano intitulada "O Amor Sagrado e o Amor Profano". Um pouco mais adiante um poema dividido em duas partes se apresenta na leitura: "I - O renascimento de Vênus", "II - O renascimento de Apolo". Num tom que lembra os versos de Ricardo Reis, cria-se uma ressignificação entre a influência clássica renascentista (Botticelli, p.ex.) e o mundo moderno europeu, em confronto com uma São Paulo que busca aqui e ali 
fontes de um europeísmo tropicalizado ("numa mitologia que atravessasse céus e oceanos para unir Atena a Xangô: naturalmente, só em São Paulo, onde todos os caminhos estão abertos, Europa e África se poderiam cruzar assim, com luz e calor, mais luz que calor", p. 36). Mais adiante ainda, surge o cenário da "Vênus Clinic", centro de cirurgia plástica. Não por acaso também, a personagem Teresa Cândida Vaz Mariscal, nome que Adriano, bilaquianamente, observa que é um decassílabo completo, tem o apelido singelo de "Flor", um monossílabo tônico, que em determinado momento na narrativa ecoa como um verso de Gertrude Stein. Flor é pintora e sua arte é resultado de um romantismo de "tempestade e ímpeto" com tons classicizantes ("Para Flor, não havia distância entre pintar e viver, mesmo que ela parecesse pintar com bolhas de sabão iridescentes", p.71), mas o mundo lá fora vai degenerando o sentido classicizante da arte ("Lá fora, a idéia grega de cidade se desintegrava.", p. 83). A filha de Adriano, Veridiana tem dificuldade de administrar a morte em acidente de automóvel do namorado, Sean Mackenzie, o que motiva um momento de tensão na primeira parte do romance. Ruas de São Paulo vão compondo um cenário dinâmico de intensa movimentação de vários personagens, como seria natural numa cidade caracterizada pela mistura de influências culturais cosmopolitas.

Isabel, irmã de Adriano, gerencia uma cantina fundada pelo pai italiano, Cláudio Dell'Acqua.

$\mathrm{Na}$ primeira parte do romance As quatro estações, justamente intitulada "Verão", São Paulo vive o verão de Vivaldi, em cujo soneto inicial, inscrito na partitura, se diz no verso 11: "E de repente inicia-se o tumulto furioso!" Ou ainda, como se lê mais adiante no romance de Carlos Morais: "Enquanto São Paulo sofria com as últimas chuvas de um Verão excessivamente cruel, a cabeça de Célio estava a treze mil quilômetros de distância", para compor a analogia com o soneto de Vivaldi: "O temor dos relâmpagos e os feros trovões" 2 .

\footnotetext{
${ }^{2}$ No original, o terceto do qual o tradutor Ricardo Matos remanejou a frase para compor o verso: " $E$ quindi Sul fiorito ameno prato । Al caro mormorio di fronde e piante |Dorme'l Caprar col fido can' à lato".
} 
A entrada do personagem Johnny Oshima, cirurgião cardiologista, em cena (Johnny era apelido, o nome verdadeiro era João) aumenta a interface com a característica cosmopolita de São Paulo, já que agora elementos culturais nipônicos são colocados em cena e para aumentar o contraste também se apresenta uma cena na quadra de samba da escola Mocidade Alegre no capítulo final da primeira parte, intitulado "Orfeu amansando as feras".

A segunda parte, "Outono" se abre com uma cena de consultório de psicanálise, Susana Klein, terapeuta especializada em jovens e adolescentes, amiga de Isabel, atende Veridiana. Importante também é o papel do personagem Raul, irmão de Flor e sócio de Célio Oshima na Venus Clinic.

Cidade de comunicações truncadas, de desencontros e reviravoltas, de relações inusitadas, como se lê neste parágrafo:

Susana (...) tentava falar com o filho, Jacques, que queria ligar para Domênica, mas se descobria sem créditos; Domênica acabara de lembrar que precisava falar uma coisa sobre a peça para João Miguel, que queria falar com João Gabriel, que ligava para Saudade, enquanto Maria do Céu ligava para João Miguel; agora era Filipinho quem queria telefonar para Sílvia, que estava ligando para Helena Thompson, que precisava falar com AnneMarie Duprat, que tinha acabado de pensar em ligar para Flor, que estava ligando para Adriano, que estava ligando para Flor... (MORAIS, 2013, p. 82)

Ciranda algo drummondiana, em que planos de vida são por vezes redirecionados por causas surpreendentes e destinos inesperados. Não falta também o papel dos migrantes nordestinos (o avô de Filipinho era um pedreiro vindo de Serra Talhada, PE).

A terceira parte, "Inverno", começa com o capítulo 7, intitulado "Uma Pintura de Nosso Amor" ("Era o primeiro dia de Inverno e São Paulo tremia inteira sob o céu mais azul que vira em meses.”, p. 322). As primeiras páginas são dominadas pelo cruzamento de intensos diálogos entre algumas personagens, tendo como pano de fundo a notícia do vernissage de Flor, que ocorre no mesmo dia em que São Paulo e todo o Brasil se entristecem com a derrota da seleção brasileira na 
Revista InterteXto / ISSN: 1981-0601

v. 6 , n. $2(2013)$

Copa do Mundo de 2010, diante da Holanda. Assim, novamente contradição de sentimentos. De um lado a festa num vernissage, signo da elite, da erudição artística para alguns, e de outro o sentimento do povo na sua posição de público do circo geral.

As coisas começam a esquentar em termos de ação, quando no ateliê de Flor ocorre a invasão de Alberto, seu antigo pretendente, que mantém a pintora e sua secretária reféns, ameaçando matá-las. Logo se instaura um cerco policial e várias personagens se envolvem na tentativa de entender o que está acontecendo; é o capítulo 8, "No Vale da Sombra da Morte". Cidade violenta em que o drama se torna espetáculo televisivo:

Quando Flor apareceu diante do ateliê, na hora os aplausos romperam, ensurdecedores. As pessoas se abraçavam, os policiais sorriam, os jornalistas falavam sem parar, contando a mesma estória com mil palavras diferentes, os helicópteros das TVs davam rasantes para conseguir a melhor imagem. (MORAIS, 2013, p. 410)

E este espetáculo vai se inserindo na narrativa como um discurso paralelo, como um olhar de um leitor virtual distante que vai buscando compor o sentido do enredo:

um quebra-cabeça com falta ou excesso de peças: o longo casamento de Flor e Adriano, as carreiras dos dois, o antigo namoro ou noivado dela com o acusado, as ligações do banco do pai dele com o Grupo Mariscal, o poderio empresarial do pai de Flor, a fama de Raul como cirurgião plástico e namorado de estrelas da TV e da moda... As rádios davam boletins de meia em meia hora, atualizando as informações sobre Flor, Rosana, Alberto. Pela internet, de uma hora para outra, o Brasil inteiro já sabia quem era Adriano Dell'Acqua e sua filha Veridiana; toda a trajetória de José Luiz Mariscal como empresário de sucesso era recontada e discutida; quando os sites de fofoca se deram conta de que Flor era irmã de uma celebridade como Raul Mariscal, todos os namoros dele foram discutidos de novo; no Twitter e no Facebook, duas ex-namoradas dele, parte de um famoso trio de modelos gêmeas, postaram até fotos de si mesmas na porta do hospital, onde diziam ter ido apoiá-lo naquela hora de dor... (MORAIS, 2013, p. 422) 
No desenvolvimento da quarta parte "Primavera", não poderia faltar, para compor o cenário de São Paulo, seus shoppings, como o do passeio de Marcelle e Alex. Tal como aqui aparece, São Paulo é a cidade que absorveu a cultura do shopping como retrato da modernidade, ou melhor, da pós-modernidade, em que o mundo se fecha num templo destinando ao consumo e, ao mesmo tempo, à exclusão da realidade exterior, que demonstra às claras a contradição:

De loja em loja, eles levavam sua felicidade, procurando apenas o que Ihes faltava: os símbolos tangíveis das amizades que tinham espalhado pelo mundo. Na lista de Marielle, estavam o casal de pássaros de cerâmica de Cynthia Gavião que há muito queria comprar para Anne-Marie, os óculos escuros de Pepeu e o celular novo que Celso queria; na de Mireille, a bolsa linda que sabia que agradaria em cheio a Isabel, "Caminhos da arquitetura", o livro de ensaios de Vilanova Artigas que Marina estava querendo, o cd de Rufus Wainwright com canções de Judy Garland para Fause e o DVD de Raphael Saadiq para Dante, de quem era o ícone máximo da elegância masculina old school. Celso estava procurando a melhor oferta para o IPAD que queria comprar para Johnny; Dante já tinha se decidido pela caixa com todas as gravações de Johnny Hartman que, tinha certeza, daria muita alegria a João Gabriel. (MORAIS, 2013, p. 577)

No romance de Carlos Morais, a cidade de São Paulo se apresenta como o ponto de cruzamento de diversos destinos, orientais, migrantes nordestinos, afrodescendentes, elite europeizada que viaja pelos mais diferentes lugares do mundo, enfim, o cruzamento de múltiplas mãos entre idas e vindas: "Era como se o clima, antes perfeito como manhã de Primavera na Grécia, enfim soubesse o que era o Inverno inglês" (MORAIS, 2013, p. 34).

E neste cenário cosmopolita, tabus, diferenças sócio-culturais se amalgamam tendo como catalisadora a própria dimensão cosmopolita da cidade. Neste sentido relacionamentos entre as mais diversas etnias e comunidades acabam surgindo.

\subsection{Em Família}


Nada mais paulistano da elite do que um casamento no Jardim Europa, na Igreja São José, em cerimônia ministrada por um padre de nome espanhol, Padre Esteban. É aí que Alex e Marcelle, filha de Walter e Júlia, amigos de Adriano e Flor, se casarão no capítulo 5 , da segunda parte, "Outono", que tem o sugestivo título de "O Vermelho da Romã Partida", elemento simbólico que representa a boa sorte, mas o adjetivo "partida" insere uma ruptura, o de se descobrir o que se tem por dentro. O capítulo é dominado pelos preparativos e pelo casamento dos jovens Alex e Marcelle. Mas Marcelle vai modificando seu padrão aos poucos, à medida que se aproxima dos valores culturais de raiz afrobrasileira, como o samba, pois, de início sua vida podia ser definida como: "a vida da Marcelle é uma linha reta, suave até o infinito: família boa, inteligência brilhante, graduação aos vinte e um, terminando o mestrado aos vinte e cinco, casamento por amor...", p. 146.

Contradição e conflito são o que sente Marcelle após conhecer o samba:

Desde o começo do ano, mais precisamente, desde o Carnaval, Marcelle não era mais a mesma, pois agora era duas. Continuava a ser a filha perfeita de Walter e Júlia, a esposa prometida de Alex, a moça responsável de sempre. Entretanto, sob a estética neoclássica de seus gestos, medidos milimetricamente para cumprir os compromissos todos de uma noiva às portas do casamento, morava, visivelmente, um vulcão, posto em erupção na quadra da Mocidade. (MORAIS, p. 254)

Posteriormente, a descoberta da identidade de seu pai biológico, Luís Francisco de Almeida, um técnico de futebol mais conhecido como Chicão Trovoada, dará sentido genético e simbólico a este fervor pelo samba que sente Marcelle.

A questão do preconceito racial na São Paulo cosmopolita já se delineia nas características da personagem Adriano ("- Que alguém com esse nome pudesse ser negro ou que um negro fosse arquiteto e ainda por cima chefe dos outros?, p. 315).

Morais dá intensidade às descrições que faz não apenas das mulheres, mas também das relações sexuais, como a que ocorre entre Dante e Mimi: 
Quando a penetrou, foi até o fundo, depois voltou, depois de novo e de novo. Sentindo-o todo dentro de si, as veias latejando, o prazer consumindo seu corpo e a alma, ela vibrava, vulcânica. Era isso, era assim que ela gostava: dobrado sobre ela, ele a apertava impossivelmente, abraçando-a, segurando-lhe os seios, suando sobre ela, dominando-a integralmente, fazendo dela o que queria, metendo gostoso (MORAIS, 2013, p. 355)

Note-se, na questão do trato com o preconceito racial, que Dante, filho de Isabel, é negro, ao passo que Mimi (Mireille Miyuki) é uma nissei que esconde dos pais o namoro.

E num mundo cosmopolita as redes sociais garantem a impossibilidade de se guardar segredos, transformam o cotidiano num reality show virtual; assim, quando Mimi fica surpresa de saber que sua família já sabia de seu namoro, ouve a explicação coerente com este contexto:

Mimi, São Paulo não é tão grande assim pra guardar um segredo desses. Você sabe quantas fotos de vocês dois estão no Facebook do Fause? Olha, depois de cada festa na época dos desfiles da Fashion Week, é garantido que seja postada pelo menos uma de vocês dois. (MORAIS, 2013, p. 433)

Assim num anticlímax, o segredo de Mimi se evapora diante da constatação ("Três anos guardando um segredo da sua mãe, uma porcaria de segredo de Polichinelo", p. 435).

Johnny e Veridiana se tornarão o casal espelho de Dante e Mimi, pois agora o masculino é o oriental e a personagem feminina é a negra. O namoro se efetiva no cenário da exposição de Emanoel Araújo, artista plástico negro que expõe no Museu Afro Brasil, fundado e dirigido por ele, mas já se anuncia num jantar em um famoso restaurante japonês da cidade:

Quando Veridiana entrou ao lado de Johnny, trouxe consigo a confusão para muitos dos olhares que se voltaram para eles. Naquele ambiente refinado, uma jovem negra era vista rara; no entanto, não havia como confundi-la como indigna dali, tal era a elegância de seus modos e a qualidade de suas roupas; até o fato de serem todas negras a igualava à maioria ali. Mas a questão ia além disso, pois ninguém ali estava à espera de uma moça negra 
entrando ao lado de um jovem oriental, ainda mais que uma aura de magnetismo os envolvia, mesmo eles não estando de mãos dadas, nem abraçados; ao sentarem-se ao tão cobiçado balcão, mantinham uma certa distância, ainda que mínima, o tempo todo. Se eram namorados, por que isso? Se eram só amigos, onde estava o resto da turma? Mesmo depois de passada a surpresa e o desconforto, por um bom tempo os olhares se cruzavam em sua direção, pois era de tal ordem a beleza de Veridiana que não havia quem não precisasse vê-la de novo - e seu jeito, ao mesmo tempo discreto e imperial, de ignorar todos ao redor, deixava um travo de mistério na atmosfera, como se só importasse a ela estar ali em nome dos prazeres do alimento e da companhia. (MORAIS, $p$. 356-357)

Convém notar que o relacionamento entre negros e orientais é o menos usual. Talvez pelo fato de os japoneses não terem historicamente feito uso de mão escrava africana, embora tivessem tentando o uso de trabalho escravo com os chineses, mas estes lhes são semelhantes em vários aspectos físicos e sócioculturais, ou ainda, porque de fato as relações históricas entre o Japão e a África foram pouco intensas. No caso específico de São Paulo, a comunidade nipônica se formou tardiamente, mas, curiosamente, para ocupar o espaço deixado pela libertação dos escravos. A comunidade japonesa se notabilizou por um fechamento à miscigenação, ao passo que o elemento afro no Brasil foi o próprio retrato da miscigenação.

O casamento de japonês com não-japônes (gaikokujin) era algo proibido pela comunidade, porém, a partir da década de 70, esse distanciamento vai diminuindo e hoje já é comum o namoro de nisseis (filhos de japoneses) ou sanseis (netos) com outras etnias no Brasil.

\subsection{As Quatro Estações: Vivaldi e Carlos Morais}

Vivaldi compôs um soneto para cada parte das Quatro Estações. A leitura destes sonetos nos permite uma analogia com o romance de Carlos Morais ao analisarmos o conteúdo dos sonetos. 
As Quatro Estações merecem a fama. Porém sua apreciação poderia ser muito melhor se juntamente com as gravações fossem divulgados os sonetos que the servem de complemento. Não é preciosismo inútil: trata-se do melhor entendimento e fruição da obra, adicionando-se importante elemento para alcançar as cenas imaginadas por Vivaldi. São quatro sonetos, um para cada concerto. Talvez os ouvintes lessem-nos durante a execução, talvez alguém os recitasse ao público adequando-os ao desenvolvimento da música. (MATTOS. 2013)

Lembro dos dois versos finais do primeiro quarteto do soneto dedicado ao outono ("Mas um tanto aceso pelo licor de Baco / Encerra com o sono estes divertimentos" ${ }^{3}$ ). E se a romã é o símbolo de um dos capítulos desta parte do romance ("O vermelho da romã partida"), no seguinte ("A serpente no jardim") se insere a figura bíblica da serpente. Neste capítulo, o mundo cão da mídia (BBB, Caras) dá um sentido tragicômico e ao mesmo fragmentário da irrealidade cotidiana, ainda mais quando se inicia um diálogo acerca do filme "Orfeu" (1950), de Jean Cocteau.

No soneto sobre o Inverno de Vivaldi, escrito no libreto de sua famosa composição, lemos, nos versos 12 e 13: "Sentir ao sair pela ferrada porta, Siroco, Borea e todos os ventos em guerra." De fato, este é a parte do romance em que a ação se tornará mais dramática e tensa, uma vez que o Inverno é o período de intensa transformação, o fim de um ciclo e o prenúncio de um reinício ao término desta estação. O capítulo 8, que está bem no meio da secção "Inverno", no romance de Morais, se denomina "No vale da sombra da morte". Os dois versos iniciais do soneto de Vivaldi fazem referência à dureza do clima de Inverno: "Agitado tremor traz a neve argêntea; Ao rigoroso expirar do severo vento." É no momento de tensão, de dificuldades que se abstraem os significados mais intensos das relações pessoais. O cap. 8 de Carlos Morais é exatamente o momento em que se dá um seqüestro, uma tentativa de assassinato e que as relações familiares são colocadas à prova.

\footnotetext{
${ }^{3}$ No original: "E del liquor di Bacco accesi tanti $\mid$ Finiscono col Sonno il lor godere."

${ }^{4}$ No original: "Sentir uscir dalle ferrate porte I Sirocco, Borea, e tutti i Venti in guerra".
} 
O capítulo "Chovem duas Chuvas", que está na primeira parte, "Verão", no enredo, se refere ao vernissage de Flor na Pinacoteca de São Paulo, que acontece na parte "Outono", leva o título de um de seus quadros, mas o título do quadro, assim como de outros da pintora, é retirado dos títulos de poemas de Cecília Meireles.

O reencontro de Adriano e Flor, após esta ficar um tempo se recuperando do seqüestro, foi ao som de "Todo azul do mar", composição de Flávio Venturini, para a letra (transcrita no romance) de Ronaldo Bastos, cantada por Adriano ("Quando a música terminou, Adriano ainda assim ficou ali, parado diante da visão do Paraíso. Flor então abriu os braços e disse: - Você veio, meu amor! E trouxe a nossa música!", p. 456). E, compondo uma analogia de Orfeu resgatando Eurídice, se transcrevem também no romance os versos de Violeta Parra, Volver a Los 17, cantada por Flor num desejo de recuperação da juventude, expressa pelo amor praticado à beira-mar.

A relação prosa, poesia, música se faz no romance de Carlos Morais de uma maneira em que a integração destes gêneros é resultado da busca de um discurso narrativo que seja representativo da própria hibridização de gêneros, característica da modernidade e da pós-modernidade. Neste sentido, também se aproxima de Vivaldi, pois no original a obra do compositor também envolvia diferentes estímulos sensoriais:

As Quatro Estações foram publicadas em Amsterdã, em 1725, com mais oito concertos em volume denominado Opera Ottava (Opus 8). As datas exatas da composição dos concertos não são conhecidas. Esse conjunto concertístico foi denominado II Cimento dell'Armonia e dell'Invenzione; um testamento artístico, tal o teor de técnica intelectual e fantasia inventiva de Vivaldi. As Quatro Estações são, acima de tudo, a celebração da rica impressão individual das mudanças de estações, inspirando a evocação do universo inteiro de emoções associadas a elas. Vivaldi esforçou-se para completar a experiência de seu público exibindo pinturas e sonetos para os músicos e para a platéia. (ATHAYDE, 2007, p. 40). 
A ordem das quatro estações em Carlos Morais não segue, porém, a ordem de Vivaldi. Em Vivaldi, o começo é na Primavera, representando a infância, depois se segue o Verão, a juventude; o Outono, a idade adulta; o Inverno representa a velhice. Carlos Morais começa pelo Verão, de modo que o Outono e o Inverno representam a quebra do equilíbrio inicial, as dificuldades que se deve transpor, é o momento dos reconhecimentos, etapa que identifica Propp na análise dos contos russos, ou seja, o conflito se intensifica e a superação dos obstáculos resulta na restauração de uma ordem perdida, de um equilíbrio recuperado. No romance, o Inverno é o instante de recuperação do equilíbrio das relações familiares e da intensificação das mesmas, a partir daí, relacionamentos apenas sugeridos se definem e um quadro de reinício do ciclo familiar toma forma. A Primavera, como parte final é o retorno ao equilíbrio inicial, de modo que a viagem de Veridiana representa o reinício do ciclo.

\subsection{O Pai e a organização familiar}

Se aprofundamos a questão das relações familiares no romance de Carlos Morais, vamos percebendo como as diferentes famílias também representam diferentes etnias e/ou grupos sociais (orientais, afro-brasileiros, descendentes europeus ou europeizados, migrantes nordestinos, famílias tradicionais) e se instauram nuclearmente, de modo que estes núcleos no cenário cosmopolita de São Paulo vão-se amoldando a uma configuração de integração e de quebra de tradições seculares e de preconceitos.

Assim, na primeira vez que Teresa observa Adriano se destaca a questão da cor da pele: "Na primeira vez em que viu Adriano, um flash atravessou a consciência de Teresa: era a primeira vez na vida que ela reparava num homem negro. Negro, sim, dos pés à cabeça, um homem bonito demais" (p. 15).

Adriano se casa com Teresa, com que tem quatro filhas, Veridiana, Marina, Domênica e Teresa Angélica. A morte do namorado de Veridiana, Sean, e depois o relacionamento dela com Johnny é uma das linhas que vai compondo este cenário de integração étnica e social. Sean Mackenzie, "um tipo exótico de 
canadense", p. 66, e Johnny, um oriental, são representantes deste cosmopolitismo que vai se infiltrando nas relações familiares, indo além das relações de trabalho. Aliás, as relações de trabalho funcionam, no mais das vezes, no romance, como estopim para o desenvolvimento das relações familiares.

A questão da paternidade é fundamental para a estratificação das relações familiares na sociedade delineada por Carlos Morais. Se Adriano assume o papel de protetor da estrutura familiar, se busca a felicidade das filhas e se nos mostra um caráter de marido apaixonado, de outro lado, o casal Walter e Júlia, que tem a filha Marcelle prestes a se casar, vive um drama relativo à paternidade. Afinal, Marcelle, ao descobrir o samba e se aperceber de como aquele ambiente da escola de samba mexe com sua identidade cultural, acaba por se reencontrar com seu verdadeiro pai, Chicão Trovoada.

As relações familiares no romance As Quatro Estações se estabelecem envolvendo três gerações, os avós, os pais e os filhos. Neste sentido, a posição dos pais é de um estado de transição conflituoso, entre os valores ancestrais e de um tempo passado, relativo à educação que tiveram, e de outro lado, os filhos, vivendo num cenário metropolitano de intensa modificação de valores e costumes.

Assim, quando José Luiz Mariscal finalmente reconhece Adriano como integrante da família que tanto prezara em termos de valores da tradição galega, e pede para que possa participar da ceia de Natal na casa do genro, lemos no romance: "Um quarto de século depois, espadas e escudos, quebrados, estavam no chão", p. 526.

\subsection{No tom do Neobarroco Latino-americano}

O cosmopolitismo paulista vai ganhando cada vez mais contornos neobarrocos na narrativa de Carlos Morais:

Beatriz já conhecia Paris, Londres, Viena, Praga, São Petersburgo Copenhagen, Nova lorque e Boston, assim como Aspen, Gstaad, Cortina d'Ampezzo e todas as melhores estações 
de esqui, mas não fazia a menor ideia de onde ficava a Vila Mariana. (MORAIS,2013, p. 484)

Neobarroco porque o que se instaura na sua narrativa é a contradição, a fragmentação, o claro-escuro, tudo permeado pelo ornamento, que vai desde a arte renascentista, ao samba, à cultura nipônica, à cultura africana.

Se o barroco é a estética dos efeitos da Contra-Reforma, o neobarroco é da contra-modernidade (...). A história oficial que hoje aparece como catástrofe é a que erigiu o Progresso, o Humanismo, a Técnica, a Cultura como categorias transcendentes para interpretar e normativizar a realidade. (CHIAMPI, 1998, p. 1819)

Notemos que o nome da personagem Veridiana, por vezes, alcunhada de Verí, significaria nestes termos a verdadeira Diana, simbolizando a passagem do panteão greco-latino para a cultura afro. Neste contexto, lembro do poema épico Omeros, de Derek Walcott (1999), com seus heróis caribenhos e negros revivendo a saga de Ulisses sob o timbre do patois crioulo das Antilhas e dos sons africanos.

A morte esperada de Pedro Júnior, pai de Filipe, amigo e sócio de Adriano, se destaca logo no início da parte IV, "Primavera". E a descida à campa se faz sob os versos de "Antífona: Em ti, ó deus, ponho a minha confiança", à guisa de ornamento artístico-religioso. Em Vivaldi, o soneto que escreveu para esta estação apresenta a sua chegada marcada pela tempestade, vindo logo após a bonança: "Uma tempestade cobre o ar com negro manto | Relâmpagos e trovões são eleitos a anunciá-la; । Logo que ela se cala, as avezinhas I Tornam de novo ao canoro encanto." 5

A cena final do romance começa a ser montada no Natal:

Assim que chegavam, todos eram envolvidos nos abraços, beijos e sorrisos que o Natal em família sempre traz, mas logo eram conduzidos, irresistivelmente, a dois pontos da casa: a

\footnotetext{
${ }^{5}$ Os dois primeiros quartetos do original: "Sotto dura Staggion dal Sole accesa | Langue L'huom, langue 'I gregge, ed arde il Pino; I Scioglie il Cucco la Voce, e tosto intesa | Canta la Tortorella e'l gardelino. II Zeffiro dolce Spira, mà contesa | Muove Borea improviso al Suo vicino; I E piange il Pastorel, perche Sospesa | Teme fiera borasca, e'l Suo destino;".
} 
cozinha, em que Adriano e Dante produziam um cardápio especial, que já se anunciava pelos cheiros que abriam todos os apetites, e o Sobradinho, onde, no térreo, onde ficavam as aquarelas de Flor, a maior parede tinha sido liberada para a instalação do imenso desenho em que Marina trabalhara nas últimas semanas. Não havia quem parasse ali e não ficasse, absorto, procurando por si mesmo. (MORAIS, 2013, p. 588)

O Natal insere-se oficialmente como data do Verão, já que a primavera termina quatro dias antes, mas historicamente se refere à substituição que fez o cristianismo da festa pagã da Brumália, dia do solstício. Assim, temos dois significados simbólicos para o romance: um é o da união familiar, do congraçamento, da fraternidade; o outro é o reinício do ciclo, pois tudo começará de novo, ciclicamente. Novos encontros e desencontros, novas mudanças de destinos, o fim e o recomeçar da vida, continuamente. O ciclo, não fechado, mas espiral, que se renova e se redimensiona, num processo próprio ao barroquismo latino-americano que se apresenta na obra de Carlos Morais.

O Neobarroco latino-americano é o espaço artístico-cultural das contradições sociais e políticas do continente. A herança colonial, fundamentada num prisma barroco que elide oposições, conflitos, de forma que o modelo europeu se contrapõe aos substratos ameríndios e afro-americanos num amálgama heterogêneo e fragmentado, é o que caracteriza as possibilidades criativas e críticas do estilo.

Alejo Carpentier, escrevendo sobre São Paulo, assim observa, comparando-a com Caracas:

O mesmo acontece com São Paulo, por exemplo, onde surgiu um neobarroquismo de concreto, de alumínio, de vidro; o barroquismo do progresso desenfreado, a um passo do serpentário do Instituto Butantã, onde as mais perigosas serpentes do solo americano avós do continente, deusas de quase todas as mitologias indígenas - vivem a eterna decadência que significa entregar o veneno de suas presas às provetas da ciência moderna. (CARPENTIER, 1987, p. 97)

Lima (1988) vê no barroco histórico dos séculos XVII e XVIII instalados e adaptados nas terras latino-americanas como o substrato que determina as características da arte moderna no continente: 
esse americano senhor barroco, autêntico primeiro instalado no que é nosso, em sua granja, canonicato ou casa bem cômoda, pobreza que dilata os prazeres da inteligência, aparece quando já se afastaram o tumulto da conquista e o parcelamento da paisagem pelo colonizador. (LIMA, 1988, p.81)

Assim, o barroco vai sedimentar a práxis cultural e artística da América Latina e nos períodos literários e artísticos subseqüentes (Neoclassicismo, Romantismo, Realismo) até se chegar às rupturas modernas, o que se tem é a continuidade desta práxis contraditória e conflituosa em sua gênese:

Esse senhor barroco exige uma dimensão: a da sua grande sala, por onde entoa a festa, com todos os lustres multiplicando os seus fogos-fátuos nos espelhos; e por onde sai a morte com seus cincerros. (LIMA, 1988, p.81-82)

Haroldo de Campos também se filia na discussão do Neobarroco latinoamericano,

E será, quem sabe, justamente no barroco, em seu transplante ibero-americano - quando a par do fusionismo próprio desse estilo, se dá a mestiçagem peculiar a um confronto de culturas e raças diferentes. (CAMPOS, 1977, p. 34-35)

. Em Morais, temos esse paradigma neobarroco, a fusão sócio-cultural de diferentes heranças culturais em São Paulo, a arte ressignificada a partir de sua matriz européia, mas, agora tratada no clima tropical, ao sabor de temperos ameríndios, afro-brasileiros, orientais, etc.

Walter sempre achava curioso como Adriano tratava uma feijoada como se estivesse diante de uma ballottine fondante de faisan servida num banquete da corte de Luís XIV, em Versalhes. As maneiras impecáveis, o guardanapo meticulosamente desdobrado sobre as pernas, a voz baixa na conversa, a recusa aristocrática da caipirinha... Nem parecia que almoçavam neste sábado, como sempre faziam quando era possível, ao lado de quase outras cem 
pessoas, na Feijoada da Bia, na Barra Funda, ambiente francamente popular e descontraído, mas que os atraíra desde há muito pela excelente feijoada, generosa como poucas em seus múltiplos sabores. (MORAIS, 2013, p. 144)

\section{E logo no início do romance, no capítulo intitulado "O Amor Sagrado e o} Amor Profano" se ressignifica o sentido da obra (Figura 1) de Ticiano, pintada por volta de 1515 e, atualmente, no acervo da Galleria Borghese:

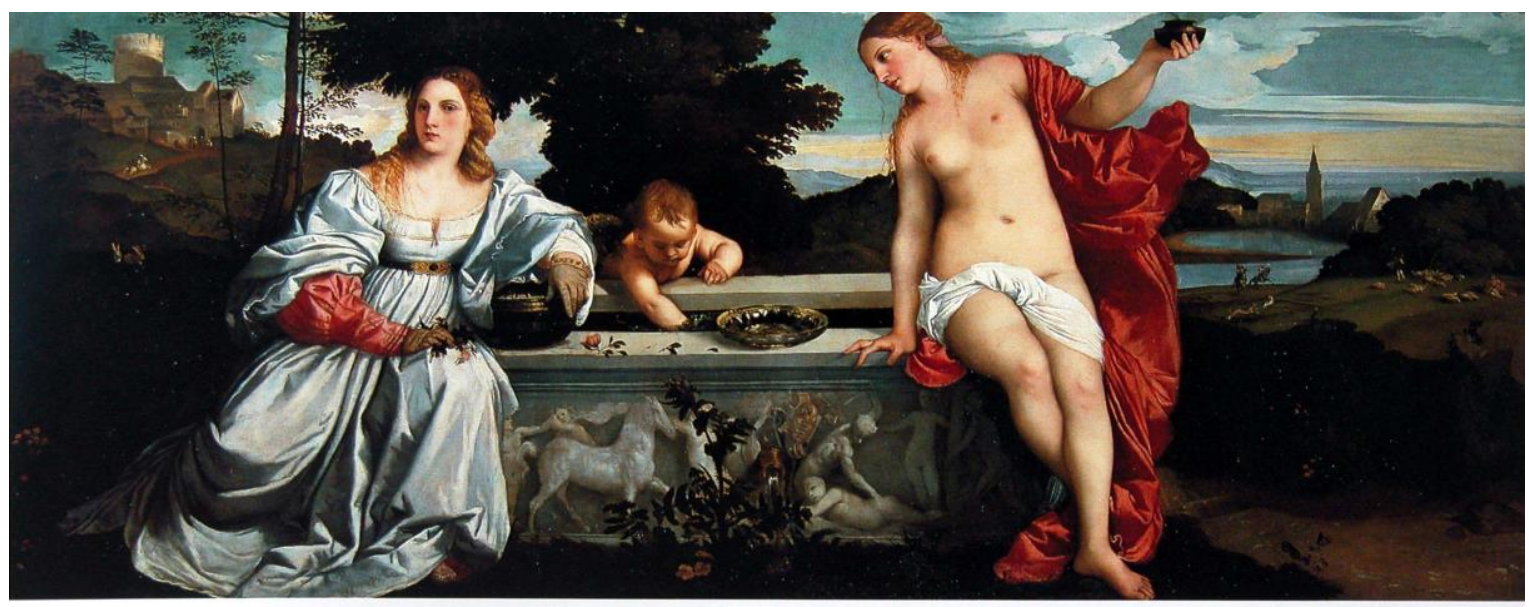

Figura 1: obra de Ticiano (1515)

Como observa Brito (2013), analisando o quadro de Ticiano:

Diferente do que supõe o título da pintura, nome dado provavelmente no final do século XVII, a obra não se trata de uma oposição entre dois tipos de amor. Existia no renascimento a crença de que a beleza sem ornamento é superior à beleza adornada, e que a forma de amor celeste, que aprecia uma beleza superior à que chamamos realidade, é mais elevada que a forma de amor terrena, que aprecia uma beleza pertencente ao mundo material. Porém, as duas formas de amor, representadas pela dupla de Vênus, buscam a beleza, cada uma à sua maneira, mas ambas são nobres e dignas de serem veneradas. Assim, segundo a interpretação do historiador da arte Erwin Panofsky, na obra está presente um diálogo de amor, dentro de um espírito de persuasão. O Cupido que mexe nas águas da fonte seria um símbolo do princípio da harmonia, em que as duas formas de amor, apesar das diferenças, seriam uma só essência. 
É a revelação de um ciclo que não se fecha propriamente, mas que se abre para um novo anel, como uma espiral a redimensionar constantemente o passado:

Seu coração disparou quando ela entendeu o que era: o cartão-postal que o Adriano tinha enviado de Roma para Flor, quase uma vida inteira atrás. Extasiada, ela olhou para Vênus, que olhava para a noiva, que olhou para ela. - Mas então a Verí sabia que eu quis este cartão a minha vida inteira! (MORAIS, 2013, p. 611)

Assim lemos no capítulo final do romance de Morais. A espiral, figura tipicamente barroca, agora neobarroca, recuperada no reinterpretar contínuo do tempo em busca de significação e de identidade próprias.

\section{A Escrita de Carlos Francisco de Morais em As Quatro Estações:}

A leitura do romance de Morais se faz, ao leitor acostumado com leituras de romances modernos, de modo eficaz, pois, aos poucos, vai sendo envolvido num cenário multifacetado, com descrições breves, mas contínuas, tanto das personagens no âmbito de suas características físicas e de suas características psicológicas, aliás, entremeadas, sem que seja possível separar uma da outra. A atmosfera de São Paulo se torna uma área de mistura de povos, influências e culturas. As referências literárias, artísticas, musicais se fazem de um modo que se integram habilidosamente ao que se está narrando ou descrevendo. Tanto nos diálogos, em geral de períodos breves e bem pontuados, quanto nas descrições ou nas digressões, a linguagem é clara, objetiva, sem, no entanto, deixar de ter o feeling para o suspense - como na cena do seqüestro, em que todos querem saber quem é o homem que prende Rosana e Flor sob a mira dum revólver.

Vejamos, para exemplificação, o penúltimo parágrafo do romance, em que Veridiana, instantes antes de embarcar para Nova lorque, entrega a Marina um presente:

Ela entregou o pequeno pacote, beijou a irmã novamente, virou-se e se foi. Em menos de um minuto, já tinha saído de vista. 
Marina então abriu o presente, sorrindo ao ver que era uma agenda de 2011 do Museu Afro Brasil, com reproduções das obras da coleção e textos sobre seus criadores. Ela já estava muito contente com a lembrança da irmã, mas, quando começou a folhear a agenda, viu que havia algo solto entre as páginas. Seu coração disparou quando ela entendeu o que era: o cartão-postal que o Adriano tinha enviado de Roma para Flor, quase uma vida inteira atrás. Extasiada, ela olhou para Vênus, que olhava para a noiva, que olhou para ela. - Mas então a Verí sabia que eu quis este cartão a minha vida inteira! (MORAIS, 2013, p. 611)

No primeiro período, os verbos "entregar", "beijar" e "virar-se" compõem quase um balé, uma seqüência de ações que determinam uma ação de despedida. O adjetivo "pequeno" e o advérbio "novamente" dão expressivamente aos verbos, tudo muito economicamente, com precisão cirúrgica. A frase a seguir, "Em menos de um minuto, já tinha saído da vista", fecha o quadro da entrega. Agora, resta ao leitor, em conjunto com Marina, descobrir seu conteúdo. Os verbos "abrir" e "sorrir" já de antemão dão ao leitor um sentido positivo ao presente dado, agora o suspense se substitui pela curiosidade, que logo se desfaz, por alguns instantes, num tom de anticlímax, é um mimo apenas: "uma agenda de 2011 do Museu Afro Brasil". Claro que não é uma agenda qualquer, o museu em questão tem significado na história que se está acabando de ler. Assim, a afirmação de que "Ela já estava muito contente com a lembrança da irmã" - notemos o advérbio de intensidade - mas o verbo auxiliar no pretérito imperfeito vem nos informar que algo se revelará neste folhear da agenda: "Havia algo solto entre as páginas". O pronome indefinido "algo" recupera o clímax há pouco desvanecido. E o período seguinte, "Seu coração disparou quando ela entendeu o que era", dá um sentido de reforço à surpresa, pois o entendimento do que era causou uma reação imediata. "Um cartão-postal, que Adriano tinha enviado de Roma para Flor, quase uma vida inteira atrás." Aqui, a oração final deste período dá um novo sentido ao termo "agenda". A agenda deve marcar o que está por vir. É a de 2011, um ano que se inicia, e o cartão-postal é do passado. Assim, se fecha o sentido cíclico das quatro estações. A idéia de ritmo cíclico se reforça na angulação, em close, para os olhares: "Extasiada, ela olhou para Vênus que olhava para a noiva, que olhou 
para ela." O período final contém a expressão "minha vida inteira!", que de fato não é inteira, está apenas começando na trilha da jovem que deve, talvez, reiniciar, o ciclo.

A sutileza da composição que se vê neste parágrafo é a tônica de todo a escritura do romance. Por vezes, quebrada, quando a intensidade dramática da cena exige, mas logo retomada para dar o sentido rítmico adequado. Aconteça o que acontecer, as estações do ano se sucedem apesar de as ações humanas configurarem um campo de contradições e conflitos. São Paulo, o cenário central, se apresenta assim, como um ponto no mapa-múndi em que as vidas se cruzam e se reconhecem.

\section{REFERÊNCIAS}

ATHAYDE, Publio. As Quatro Estações: Mimese. Monografia apresentada como trabalho de conclusão do XV Curso de Pós-Graduação Lato Sensu em Cultura e Arte Barroca, Instituto de Filosofia, Artes e Cultura da Universidade Federal de Ouro Preto; redigida sob orientação do Prof.Dr. João Adolfo Hansen. Ouro Preto, 2007. 136p.

BRITO, Carla. Análise da obra "O Amor Sagrado e o Amor Profano. 2013. Disponível em: <http://estoriasdahistoria12.blogspot.com.br/2013/12/analise-daobraamor-sagrado-e-amor.html>. Acesso em agost. 2013.

CAMPOS, Haroldo de. Ruptura dos Gêneros na Literatura Latino-Americana. São Paulo, Perspectiva, col. Elos, v. 6, 1977.

CARPENTIER, Alejo. A Literatura do Maravilhoso. São Paulo, Vértice, 1987.

CHIAMPI, Irlemar. Barroco e Modernidade. São Paulo, Perspectiva, 1998.

LIMA, Lezama. A Expressão Americana. Trad., Introdução e Notas de Irlemar Chiampi. São Paulo, Brasiliense, 1988.

MATTOS, Ricardo de. "Da Poesia Na Música de Vivaldi" em: Digestivo Cultural, publicado em 06/02/2013. Acessado em:

http://www.digestivocultural.com/colunistas/coluna. asp?codigo=925\&titulo=Da Po esia $\mathrm{Na}$ Musica de Vivaldi.

MORAIS, Carlos Francisco. As Quatro Estações. 2013. Trabalho inédito. 
Revista InterteXto / ISSN: 1981-0601

v. 6, n. $2(2013)$

WALCOTT, Derek. Omeros. Trad. E prefácio Paulo Vizioli. São Paulo, Cia. Das Letras, 1999. 